\title{
Associations of Living Environment and Lifestyle Factors with Sub-Health Status: A Population-Based Cross-Sectional Study in Urban China
}

\author{
Yefang Feng \\ Southern Medical University Nanfang Hospital

\section{Yunlian Xue} \\ Southern Medical University Nanfang Hospital \\ Guihao Liu \\ GuangDong Provincial People Hospital \\ Mengyao Xu \\ Southern Medical University Nanfang Hospital \\ Lijie Jiang \\ Yuanqi Lin \\ Southern Medical University Nanfang Hospital

\section{Chengkai Wu} \\ Southern Medical University Nanfang Hospital

\section{Wenyuan Li} \\ Southern Medical University Nanfang Hospital

\section{Jun Xu ( $\sim$ drugstat@163.com )} \\ Southern Medical University Nanfang Hospital
}

Southern Medical University Nanfang Hospital Department of Spinal Surgery

\section{Research}

Keywords: Sub-health status, lifestyle behaviors, environment, urban residents, China

Posted Date: July 2nd, 2020

DOI: https://doi.org/10.21203/rs.3.rs-38413/v1

License: (c) (i) This work is licensed under a Creative Commons Attribution 4.0 International License. Read Full License 


\section{Abstract}

Background: Sub-health status (SHS) is an increasingly concerned issue with a high prevalence worldwide. Although some factors of lifestyle and environment has been study, few studies have determined comprehensively the associations of lifestyle and living environmental factors with general, physical, mental and social SHS.

Methods: A cross-sectional face-to-face survey (Sep 2017 to Sep 2018) was conducted via questionnaire among 6,750 urban residents aged 14 years and above randomly selected from five Chinese cities. There were 5,881 valid questionnaires with a response rate of $87 \%$. General linear model and structure equation model were developed to quantifying the effects of lifestyle behaviors and living environmental factors on SHS.

Results: Detection rates of general SHS, physical SHS, mental SHS and social SHS were $66.7 \%, 67.0 \%, 65.5 \%$ and $70.0 \%$, respectively. Significant association of general SHS, physical SHS, mental SHS and social SHS had been found in smoking, bad dietary habits, breakfast consumption, physical exercise, sleep duration, air, neighbor harmony and living convenience, instead of noiseless. However, associations of general SHS, physical SHS, mental SHS and social SHS were different for second-hand smoking influence, alcohol consumption, sunshine, Bedtime before $11 \mathrm{pm}$, surfing the internet, greenery, air, pleasant housing, spacious rooms and fitness facility. Good lifestyle behaviors and favorable living environment factors positively affected SHS $(P<0.001)$. Lifestyle behaviors had the largest effect on physical SHS $(\beta=-0.418)$, but the least on social SHS $(\beta=-0.274)$. Living environmental factors had the largest effect on mental SHS $(\beta=0.286)$, but the least on physical SHS $(\beta=0.225)$.

Conclusions: Lifestyle behaviors and living environmental factors were important influencing factors of SHS. Physical SHS was more associated with lifestyle. Lifestyle and living environment were similarly associated with mental and social SHS.

\section{Background}

Health is defined by the World Health Organization (WHO) in 1946 as "a state of complete physical, mental, and social well-being and not merely the absence of disease or infirmity"[1, 2]. Noncommunicable Chronic diseases (NCDs) are the opposite side of health, and are great challenges to health. It is reported that NCDs account for an estimated $80 \%$ of total deaths and $70 \%$ of the total number of disability-adjusted life-years (DALYs) in early twentieth century[3], and increase steadily with the urbanization and aging [4], with more than $88 \%$ of total deaths due to NCDs in 2019 in China[5]. A study pointed that NCDs accounted for 18 of the leading 20 causes of age-standardized years lived with disability on a global scale[6]. Preclinical status of CNDs and its early detection have become major issues in the promotion of the basic health service in the reform of health care[7].

Some studies have shown that SHS or suboptimal health status (SHS) may contribute to the progression or development of chronic disease[8, 9]. SHS is an intermediate status between chronic disease and health, which is characterized by chronic fatigue, non-specific pain (e.g., back and chest pain), headaches, dizziness, anxiety, depression, and functional system disorders [8]. SHS has a prevalence of higher than 65\% in China[10-13]. and become an increasingly concerned problem in many other countries $[14,15]$. Moreover, the prevalence may be severely underestimated since many individuals may not know that they suffer from SHS. For instance, in an investigation of 6,000 Chinese self-reported "healthy people", 72.8\% were in "suboptimal health status" [16]. Identifying the influencing factors of SHS is important for preventing SHS, and would provide important information for first-level prevention of CND.

In the recent decades, China underwent a rapid urbanization development, with a proportion of urban population increased from $17.9 \%$ in 1978 to 58.5\% in 2017[17]. The rapid environmental changes accompanied with urbanization lead to the increasing prevalence of the major risk factors for SHS, including poor dietary habits, work stress, physical 
inactivity, breakfast eating habits, smoking, tobacco use, air pollution and noise[2, 18, 19]. Those risk factors can be concluded into two aspects, lifestyle behaviors and living environmental factors. Although, lifestyle behaviors and living environmental factors associated with SHS has been studied before, the association strengths of the two aspects with SHS have not been well elucidated.

This study aimed to examine the associations of lifestyle behaviors and the living environmental factors with general, physical, mental and social SHS in a large urban population.

\section{Methods}

\section{Study Design and Population}

We conducted a cross-sectional multi-city survey using a four-stage stratified sampling method from Sep 2017 to Sep 2018. In stage one, we selected Guangdong Province (south east China), Haerbin City in Heilongjiang Province (north east), Sichuan Province (north west), Tianjin City (east), and Lanzhou City in Gansu Province (south west) as representative of different Chinese regions from the aspects of geographic distribution, economic characteristics, and populational demographics. Figure 1 shows the sampling map in China. In stage two, three to five cities in each province were selected as respective representatives of geographic distribution, economic characteristics, and populational demographics. In stage three, two cities were randomly selected from each of these areas. In the fourth and final stage, one to three streets were randomly selected from each of these cities. To ensure representativeness, participants on each street were stratified according to sex (i.e., male or female) and age (i.e., brackets of $14-24,25-34,35-44$, 45-54, and 55+). At the selected streets, street sampling method was used to select participants. As such, survey participants were representative of the level of SHS in their respective urban areas.

Informed oral consent was obtained from each participant prior to the data collection process. This form of consent was deemed sufficient as participants had previously volunteered for inclusion and were told they could still refuse to participate. All data were kept strictly confidential. Further, the Nanfang hospital ethics committee approved this consent procedure(Approval number: NFEC-2019-196) .

\section{Survey Instrument}

This study used a SHS questionnaire to investigate urban Chinese residents. It contained two sections (i.e., both a selfdesigned and standardized questionnaire) [10]. The self-designed questionnaire asked for general demographic characteristics as well as information on lifestyle and environment. Here, general demographic characteristic included age, gender, and marital status, while there were 10 lifestyle variables (i.e., smoking, second-hand smoking, alcohol consumption, bad dietary habits, breakfast consumption, sun exposure, physical exercise, early bedtime (before 11 pm), sleep duration, and surfing the internet), and eight environmental variables (i.e., air quality, noise, housing conditions, living conditions, neighborhood harmony, fitness facilities, and supporting facilities). The standardized components were based on the SHS Measurement Scale V1.0 (SHMS V1.0); these were designed to assess participant health status. Uniform instructions were provided by trained investigators. Each participant completed their own questionnaire in approximately 25 minutes.

\section{SHS Assessment}

Health-status assessments were performed in accordance with the SHMS V1.0, which was previously developed by our research group. Testing procedures revealed that it was of high reliability and validity (Cronbach's a and split-half 
reliability coefficients of 0.917 and 0.831 , respectively)[20]. The SHMS V1.0 consists of 39 total items. Respondents were asked to answer each of these items according to a 5-point scale (1 to 5, from very bad to very good). The SHMS V1.0 can be used to detect general SHS (GS) based on three symptom dimensions, including physical SHS (PS), mental SHS (MS), and social SHS (SS). Of the 39 total items, Nos. 4-12, 15, 20-25, 28, and 38-39 were reverse scored (six plus the original score). The original subscale scores were total item sums; higher original scores indicated better health. We calculated and analyzed transformed scores to further understand and compare the data. Transformed scores were determined according to the following formula: (original score - theoretically lowest score) / (theoretically highest score theoretically lowest score) $\times 100$. Following our previous study, SHS prevalence was calculated based on transformed scores[21].

\section{Statistical Analysis}

A general linear model was used to analyze the association of lifestyles (environmental factors) and SHS as adjusted by demographic characteristics and living environmental factors (lifestyles). Further, a path model of latent variables was constructed based on a hypothesized relationship between items. Structural equation modeling (SEM) was then used to analyze the complexity of associations between lifestyle, health consciousness, and SHS to estimate model fitness and analyze the direct and indirect effects of the multiple factors used in the hypothesized model[22]. Model fitness was assessed using the five indices commonly applied in SEM analyses (i.e., the relative (CMIN/DF), root mean-square error of approximation (RMSEA), comparative fit index (CFI), goodness-of-fit index (GFI), and adjusted goodness-of-fit index (AGFI)) [23]. The Bootstrapping method[22] of repeat sampling (i.e., 2,000 times) was applied to verify statistical significance and calculate confidence intervals for the direct, indirect, and total effects $(P<0.05)$. All statistical analyses were conducted using SPSS and AMOS (SPSS Statistics version 20.0, SPSS Inc., Chicago, IL). Two-sided p-values $<0.05$ were considered statistically significant.

\section{Results}

\section{Participant Demographic Characteristics}

This study surveyed a total of 6,750 urban Chinese residents who had lived in their locations for more than six months and were at least 14 years of age. A total of 807 participants who confirmed they had incurred diseases within one month of the study were excluded. As such, 5,943 respondents were either healthy or SHS for at least a period of one month prior to study. However, 62 of these surveys were missing values for items of lifestyle, environment, and/or SHS, and were thus excluded. This left a final total of 5,881 urban residents who were selected for analysis (a valid response rate of $87.13 \%$ ).

Table 1 presents overall baseline, lifestyle, and environmental characteristics. Of the 5,881 analyzed, 2,817 were men and 3,064 were women; mean age was $40.27 \pm 15.69$ years. Most participants were married (64.50\%). Further, $66.7 \%$ were in GS, $67.0 \%$ were in PS, $65.5 \%$ were in $\mathrm{MS}$, and $70.0 \%$ were in SS.

\section{Comparison of SHS for Different Lifestyle and living environmental factors}

The mean (sd) transformed scores for general, physical, mental, and social sub-health status were 67.23 (12.03), 71.08 (12.70), 67.04 (14.63), 61.47 (15.65), respectively. Here, the association of one lifestyle factor with SHS was adjusted by other lifestyle behaviors, demographical characteristics, and living environmental factors (Table 2). Participants who never smoked, had good dietary habits, consumed breakfast daily, performed daily physical exercise, and slept 7-9 hours each night had the highest general, physical, mental, and SS transformed scores. Participants who had not received 
second-hand smoke and never used alcohol had the highest general, physical, and MS transformed scores. Participants who maintained bedtimes before $11 \mathrm{pm}$ each day had the highest general and PS transformed scores. Sun exposure was only associated with PS; those who received 14 hours or more each week had the highest scores. Surfing the internet was only associated with MS; those who surfed less than three hours a day had the highest scores.

Table 3 shows the effects of environmental factor after adjusting other living environmental factors, demographic characteristics, and lifestyle behaviors. Pleasant housing, harmonious neighborhoods, and convenient living conditions were positively associated with general, physical, mental, and SS. Substantial greenery was positively associated with general and SS. Fresh air was positively associated with general, physical, and MS. The presence of many fitness facilities was positively associated with general and MS. There were no significant associations between noise and SHS. However, people with spacious rooms in their homes had lower general and MS scores.

\section{SEM Analysis of Lifestyle, Environment, and SHS}

The total associations of lifestyle behaviors and environment with SHS were analyzed through SEM (Fig. 2). Although noiseless areas were not independently associated with SHS, the model was not deemed fit without an environmental noise component. The SEM thus included a "noiseless" variable. Except for the CMIN/DF, CFI, and AGFI of Model 1 and the CMIN/DF of Model 2, Table 4 presents information about the fitness measurements for all four models. The associations of lifestyle and living environmental factors with SHS are listed in Table 5. As indicated, bad lifestyle habits had significant negative effects on general, physical, mental, and SS, while good living environmental factors had significant positive effects on each $(P<0.001)$. Lifestyle had the largest effect on PS $(\beta=-0.418)$ and the least effect on SS $(\beta=-0.274)$. On the other hand, living environmental factors had the largest effect on MS $(\beta=0.286)$ and the least effect on PS $(\beta=0.225)$. As the influencing effects were standardized, GS had larger association with lifestyle $(\beta=-0.371)$, but less with environment $(\beta=-0.282)$; physical health was more associated with lifestyle $(\beta=-0.418)$, but less associated with environment $(\beta=-0.225)$. The associations of lifestyle behaviors and environment were similar for MS and identical for SS.

\section{Discussion}

This cross-sectional study of nationally representative urban Chinese residents found that lifestyle behaviors and living environmental factors were significantly associated with SHS. The association strengths between lifestyle behaviors and GS, lifestyle behaviors and PS were bigger than those of living environmental factors. The association of lifestyle behaviors and MS, lifestyle behaviors and SS were almost the same with those of living environmental factors.

To the best of our knowledge, this was the first study on the association strengths of lifestyle behaviors and living environmental factors with SHS. The findings concluded in this study were generally in line with previous studies on the relationship between lifestyle and PS[24, 25]. Innovative findings in this study were the significant associations between living environmental factors and MS, living environmental factors and SS. Although, the association between living environmental factors and mental health has been elucidated before.

This study used the 39-item SHMS V.1.0 questionnaire to analyze SHS. It included physical, mental, and social dimensions. Our previous research indicated that SHMS V.1.0 had good internal consistency among both a population of southern Chinese medical staff members[21] and urban residents in three Chinese districts[26]; Detective rate of GS in Chinese urban residents was $66.7 \%$, slightly higher than southern China (65.1\%) [13] and Tianjin (66.37\%) [14].

This study found that bad lifestyle habits such as smoking, alcohol consumption, second-hand smoking influences, poor dietary habits, and surfing the internet were associated with low SHS scores. On the other hand, good lifestyle habits such as taking daily breakfast, sufficient sun exposure, daily physical exercise, consistently going to bed before 11 pm, and 
daily sleep durations between 7-9 hours were associated with non-SHS. A study among Chinese university students similarly indicated that sleep durations of less than six hours per day were independently and significantly associated with poor self-reported health[27]. Skipping breakfast has also been found in association with a significantly increased risk of mortality from cardiovascular disease[28]. Further, an English study pointed out that poor health outcomes were more common among ex-smokers and current smokers than those who had never smoked[29]. Finally, alcohol use and short sleep durations are likely related to poor health among black men living in the United States[30].

Many studies have indicated that exercise, physical activity, and physical-activity interventions are beneficial for several physical and mental-health outcomes. Sufficient fresh air and sun exposure are also good for promoting public health[31]. Taken together, these studies and our findings underscore the importance of maintaining good lifestyle habits while abandoning bad choices as a simple way to prevent SHS and increase overall health.

This study further found that living environmental factors such as sufficient greenery, fresh air, pleasant housing, less spacious rooms, harmonious neighborhoods, the presence of many fitness facilities, and convenient living conditions were associated with high SHS scores. It is well-known that positive environments (especially natural outdoor areas) are good for human health[32]. Contrary to our general expectations, however, we found that people who lived in spacious rooms had a greater probability of developing both mental and GS. This may be due to feelings of emptiness in one's surroundings. For example, a systematic review indicated that living alone may be associated with low levels of positive mental health[33].

\section{Study Strengths}

This population-based study examined a sample of urban residents (5,881 respondents), thus facilitating overall generalizability to the entire urban population in China. Further, we illustrated the relative strengths of lifestyle behaviors and living environmental factors on the associations with SHS. We firstly illustrated the important association of living environmental factors and MS, living environmental factors and SS, which almost the same with lifestyle behaviors. What's more, association factors were comprehensive, including 10 lifestyle behaviors and eight living environmental factors, which can be intervened and was helpful for preventing of SHS and chronic noncommunicable diseases.

\section{Limitations}

First, because of the cross-sectional design, it was not possible to confirm causal relationships of SHS with lifestyle behaviors and living environmental factors. Second, lifestyle factors were self-reported in this study, which reduced the precision of measurement of lifestyle behaviors and living environmental factors. Third, although we have considered as many factors as possible, bias may happen inevitably due to some factors not being included.

\section{Conclusions}

This large-scale cross-sectional study of Chinese urban residents aged 14 and above found that good lifestyle behaviors and living environmental factors were both significantly associated with low rates of SHS (i.e., high SHS scores). Lifestyle behaviors were more significantly associated with physical and GS. However, living environmental factors and lifestyle behaviors were nearly identically associated with mental and SS.

\section{Abbreviations}

SHS: sub-health status 
GS: general sub-health status

PS: physical sub-health status

MS: mental sub-health status

SS: social sub-health status,

SEM: Structural equation model

CMIN/DF: relative $\mathrm{x}^{2}$

RMSEA: root mean-square error of approximation

CFI: comparative fit index

GFI: goodness-of-fit index

AGFI: adjusted goodness-of-fit index

\section{Declarations}

\section{Ethics approval and consent to participate}

The study protocol was approved by Medical Ethics committee of NanFang Hospital of Southern Medical University (NFEC-2019-196).

\section{Consent for publication}

Not applicable.

\section{Availability of data and materials}

Data used in this study were obtained under the support of Nanfang Hospital, Southern Medical University. The ownership of the data belongs to Nanfang Hospital, Southern Medical University. Researchers who meet the criteria for access to confidential data can contact Jun Xu (drugstat@163.com) at the Nanfang Hospital, Southern Medical University to request the data.

\section{Competing interests}

None declared.

\section{Funding}

This research was supported by the National Natural Science Fund, National Natural Science Foundation of China (No: 71673126), and the Science and Technology Planning Project of Guangzhou City of China (No: 201803010089). 


\section{Authors' contributions}

$\mathrm{XYL}$ did the analysis and interpretation of data, and wrote the manuscript. $\mathrm{XJ}$ initiated and designed the survey. LWY provided supporting for the survey. LGH, FYF, XMY were contributed to the national survey. XJ and LWY revised the manuscript. All authors read and approved the final manuscript.

\section{Acknowledgments}

The authors thank all study participants. We also thank the investigators and students for their assistance in this research.

\section{References}

1. Grad F.P. The preamble of the constitution of the World Health Organization. Bull. World Health Organ. 2002;80:981984.

2. JL Bi, Ying H, Ya X, JR Cheng, Fei L, Tian W, et al. Association of lifestyle factors and suboptimal health status: A cross-sectional study of Chinese students. Bmj Open, 2014, 4(6):e005156.

3. Strong K, Mathers C, Leeder S, Beaglehole R. Preventing chronic diseases: how many lives can we save? Lancet. 2005;366:1578-82

4. Wang L, Kong LZ, Wu F, Bai YM, Burton R. Preventing chronic diseases in China. Lancet. 2005;366:1821-4.

5. Transcript of press conference of the office of Health China action Promotion Committee on July 31, 2019. http://www.nhc.gov.cn/xcs/s7847/201907/0d95adec49f84810a6d45a0a1e997d67.shtml

6. GBD 2015 Mortality and Causes of Death Collaborators. Global, regional, and national life expectancy, all-cause mortality, and cause-specific mortality for 249 causes of death, 1980-2015: a systematic analysis for the Global Burden of Disease Study 2015. Lancet. 2016;388(10053):1459-1544.

7. Wang Y., Ge S., Yan Y., Wang A., Zhao Z., Yu X., Qiu J., Alzain M.A., Wang H., Fang H., et al. China suboptimal health cohort study: Rationale, design and baseline characteristics. Transl. Med. 2016;14:291-302. .

8. Yan YX, Dong J, Liu YQ, Zhang J, Song MS, He Y, Wang W. Association of suboptimal health status with psychosocial stress, plasma cortisol and mRNA expression of glucocorticoid receptor $\alpha / \beta$ in lymphocyte. Stress. 2015;18(1):29-34.

9. Yan Y, Dong J, Liu Y, Yang X, Li M, Shia G, et al. Association of Suboptimal Health Status and Cardiovascular Risk Factors in Urban Chinese Workers[J]. Journal of Urban Health, 2012, 89(2):329-338.

10. Xue YL, Xu J, Liu GH, Feng Y, Xu M, Xie J, et al. Study of association between personality and sub-health status among urban residents aged more than 14 years old in 4 cities in China. J Southern Med Univ. 2019,39(4): 443-449.

11. Xue YL, Xu J, Liu GH, Feng Y, Xu M, Xie J, et al. The mediating effect of adversity quotient on the correlation between stressful life events and sub-health status. Modern Preventive Medicine. 2019,46(1):82-85,90.

12. Sun X, Wei M, Zhu C, Wang XL, Zhao XS, Luo R. The epidemiological investigation of sub-health status in Guangdong. Shandong Med J. 2008; 48:59-60

13. Xie J囚Luo HB囚Zhu H, Chang WJ, Xu J. Prevalence and influence factors of sub-health status among urban residents in Tianjin. Chin J Public Health. 2016; 32: 76-80.

14. Sou J, Goldenberg S M, Duff P, Nguyen P, Shoveller J, Shannon K. Recent im/migration to Canada linked to unmet health needs among sex workers in Vancouver, Canada: Findings of a longitudinal study. Issues in Health Care of Women. 2017; 38(5):492-506. 
15. Dunstan RH, Sparkes DL, Roberts TK, Crompton MJ, Gottfries J, Dascombe BJ. Development of a complex amino acid supplement, Fatigue Reviva, for oral ingestion: initial evaluations of product concept and impact on symptoms of suboptimal health in a group of males. Nutrition Journal. 2013; 12:115.

16. Liu Z, Li M. The third state and psychosomatic medicine research. Med Philosophy. 2001;22(1):36-8.

17. RX Jia. China's 40 Years of Urbanization: From High Speed to High Quality. China Development Watch. 2018; 204(24):19-23.

18. JY Chen, JR Cheng, YY Liu, Y Tang, XM Sun, T Wang, et al. Associations between breakfast eating habits and healthpromoting lifestyle, suboptimal health status in Southern China: a population based, cross sectional study. Journal of Translational Medicine, 12(1):348.

19. Ma N., Liu M. Research progress on the epidemiology of sub-health state. China Prev. Med. 2012;7:556-559.

20. Xu J, Feng LY, Luo R, Qiu JC, Zhang JH, Zhao XS, et al. Assessment of the reliability and validity of the Sub-health status Measurement Scale Version1.0. J Southern Med Univ. 2011;31(1):33-38.

21. Xu J, Xue YL, Liu GH, Feng Y, Xu M, Xie J, et al. Establishment of the norms of Sub-health status measurement scale version 1.0 for Chinese urban residents. J South Med Univ. 2019;29(3): 271-278.

22. Bucy EP, Holbert RL. Sourcebook for political communication research: methods, measures, and analytical techniques. New York: Routledge. 2014.

23. Yamaga E, Sato Y, Minakuchi S. A structural equation model to test a conceptual framework of oral health in Japanese edentulous patients with an item weighting method using factor score weights: a cross-sectional study. Bmc Oral Health. 2018; 18:71-9.

24. Minich DM, Bland JS. Personalized Lifestyle Medicine: Relevance for Nutrition and Lifestyle Recommendations. The Scientific World Journal. 2013;129841

25. Marques A, Peralta M, Santos T, Martins J, Gaspar de Matos M. Self-rated health and health-related quality of life are related with adolescents' healthy lifestyle. Public Health.2019;170:89-94.

26. Lu Y, Xu J, Cai YJ, Xie J, Qiu JC, Wei Q. Reliability and Validity of Sub-health status Measurement Scale Version 1.0 for Measuring the Sub-health status of Urban Residents in Three Districts. China Journal of Health Psychology. 2013;21(5):707-8.

27. Li L, Lok KI, Mei SL, Cui XL, Li L, Ng CH, et al. Sleep duration and self-rated health in Chinese university students. Sleep Breath. 2019 May 31.

28. Rong S, Snetselaar LG, Xu GF, Sun Y, Liu B, Wallace RB, et al. Association of Skipping Breakfast With Cardiovascular and All-Cause Mortality. JAMA. 2019, 73(16): 2025-2032.

29. Chattopadhyay K, Akagwire U, Biswas M, Moore R, Rajania G, Lewis S. Role of lifestyle behaviours in the ethnic pattern of poor health outcomes in Leicester, England: analysis of a survey data set. Public Health. 2019,170:122128.

30. Jackson CL, Gaston SA, Liu R, Mukamal K, Rimm EB. The Relationship between Alcohol Drinking Patterns and Sleep Duration among Black and White Men and Women in the United States. International Journal of Environmental Research and Public Health, 2018, 15(3):557.

31. Keeling AW. Historical Perspectives on Fresh Air, Sunshine, and Public Health. Windows Time. 2015;23(2):1-2.

32. Zijlema WL, Christian H, Triguero-Mas M, Cirach M, van den Berg M, Maas J, et al. Dog ownership, the natural outdoor environment and health: a cross-sectional study. BMJ Open. 2019;9(5):e023000.

33. Tamminen N, Kettunen T, Martelin T, Reinikainen J, Solin P. Living alone and positive mental health: a systematic review. Syst Rev. 2019;8(1):134.

\section{Tables}


Table 1

Frequency distribution of participant demographic characteristics $(n=5881)$

\begin{tabular}{|c|c|c|c|c|c|}
\hline Characteristic & $\mathbf{N}$ & $\begin{array}{l}\text { GS } \\
\text { (mean (sd)) }\end{array}$ & $\begin{array}{l}\text { PS } \\
\text { (mean (sd)) }\end{array}$ & $\begin{array}{l}\text { MS } \\
\text { (mean (sd)) }\end{array}$ & $\begin{array}{l}\text { SS } \\
\text { (mean (sd)) }\end{array}$ \\
\hline \multicolumn{6}{|l|}{ Gender } \\
\hline Male & 2817 (47.9) & 71.24 (12.65) & $68.13(14.6)$ & 61.39 (16.03) & $67.64(12.11)$ \\
\hline Female & 3064 (52.1) & 70.93 (12.75) & 66.05 (14.58) & 61.56 (15.3) & 66.85 (11.95) \\
\hline \multicolumn{6}{|l|}{ Age } \\
\hline $14-24$ & 1129 (19.2) & 72.65 (12.19) & $65.01(13.87)$ & $60.85(15.82)$ & 72.65 (12.19) \\
\hline $25-34$ & 1167 (19.84) & 72.21 (12.76) & $65.97(14.93)$ & $60.92(15.61)$ & 72.21 (12.76) \\
\hline $35-44$ & 1345 (22.87) & 71.28 (12.96) & $67.3(14.61)$ & 61.48 (15.22) & 71.28 (12.96) \\
\hline $45-54$ & $1120(19.04)$ & 70.05 (12.08) & $68.56(14.32)$ & $62.57(15.5)$ & 70.05 (12.08) \\
\hline$\geq 55$ & $1120(19.04)$ & $69.54(12.92)$ & 69 (15.04) & 61.53 (15.69) & 69.54 (12.92) \\
\hline \multicolumn{6}{|l|}{ Marital status } \\
\hline Unmarried & $1673(28.45)$ & 72.25 (12.31) & $64.96(14.31)$ & $60.51(15.64)$ & 66.73 (11.64) \\
\hline Married & $3793(64.5)$ & 71.03 (12.69) & $68.42(14.51)$ & $62.16(15.38)$ & 67.85 (11.99) \\
\hline Divorced & $200(3.4)$ & $66.79(13.15)$ & $62.7(14.4)$ & $58.57(18.02)$ & $63.28(13.11)$ \\
\hline Widowed & $183(3.11)$ & $66.84(13.75)$ & $63.24(16.18)$ & 60.17 (17.38) & 63.89 (13.32) \\
\hline Information missing & $32(0.54)$ & 67.24 (13.96) & $61.33(14.22)$ & $56.34(16.91)$ & $62.41(12.54)$ \\
\hline
\end{tabular}


Table 2

Comparison of SHS with different lifestyle behaviors (mean (sd))

\begin{tabular}{|c|c|c|c|c|c|c|c|c|c|c|}
\hline \multirow[t]{2}{*}{ Variables } & & \multirow[t]{2}{*}{$\mathbf{N}$} & \multicolumn{2}{|l|}{ GS } & \multicolumn{2}{|l|}{ PS } & \multicolumn{2}{|l|}{ MS } & \multicolumn{2}{|l|}{ SS } \\
\hline & & & $\begin{array}{l}\text { mean } \\
\text { (sd) }\end{array}$ & $\begin{array}{l}P \\
\text { value }\end{array}$ & $\begin{array}{l}\text { mean } \\
\text { (sd) }\end{array}$ & $\begin{array}{l}P \\
\text { value }\end{array}$ & $\begin{array}{l}\text { mean } \\
\text { (sd) }\end{array}$ & $\begin{array}{l}P \\
\text { value }\end{array}$ & $\begin{array}{l}\text { mean } \\
\text { (sd) }\end{array}$ & $\begin{array}{l}\mathrm{P} \\
\text { value }\end{array}$ \\
\hline \multirow[t]{4}{*}{ Smoking } & & & & $<.001$ & & $<0.001$ & & 0.001 & & $<.001$ \\
\hline & never & 4079 & $\begin{array}{l}67.67 \\
(11.8)\end{array}$ & & $\begin{array}{l}71.7 \\
(12.5)\end{array}$ & & $\begin{array}{l}67.15 \\
(14.55)\end{array}$ & & $\begin{array}{l}62.1 \\
(15.26)\end{array}$ & \\
\hline & quit & 615 & $\begin{array}{l}64.79 \\
(13.06)\end{array}$ & & $\begin{array}{l}68.37 \\
(13.57)\end{array}$ & & $\begin{array}{l}65.37 \\
(15.11)\end{array}$ & & $\begin{array}{l}58.44 \\
(17.4)\end{array}$ & \\
\hline & yes & 1187 & $\begin{array}{l}66.95 \\
(12.12)\end{array}$ & & $\begin{array}{l}70.35 \\
(12.7)\end{array}$ & & $\begin{array}{l}67.53 \\
(14.6)\end{array}$ & & $\begin{array}{l}60.9 \\
(15.86)\end{array}$ & \\
\hline \multirow{5}{*}{$\begin{array}{l}\text { Second-hand } \\
\text { smoking } \\
\text { influence }\end{array}$} & & & & $<.001$ & & $<.001$ & & 0.001 & & 0.376 \\
\hline & none & 1150 & $\begin{array}{l}68.95 \\
(12.73)\end{array}$ & & $\begin{array}{l}72.94 \\
(12.99)\end{array}$ & & $\begin{array}{l}68.97 \\
(15.61)\end{array}$ & & $\begin{array}{l}62.72 \\
(16.88)\end{array}$ & \\
\hline & little & 1804 & $\begin{array}{l}67.54 \\
(12.03)\end{array}$ & & $\begin{array}{l}71.68 \\
(12.72)\end{array}$ & & $\begin{array}{l}67.31 \\
(14.29)\end{array}$ & & $\begin{array}{l}61.41 \\
(15.68)\end{array}$ & \\
\hline & some & 1702 & $\begin{array}{l}66.6 \\
(11.21)\end{array}$ & & $\begin{array}{l}70.31 \\
(12.32)\end{array}$ & & $\begin{array}{l}66.55 \\
(13.62)\end{array}$ & & $\begin{array}{l}60.92 \\
(14.51)\end{array}$ & \\
\hline & much & 1225 & $\begin{array}{l}66 \\
(12.25)\end{array}$ & & $\begin{array}{l}69.52 \\
(12.65)\end{array}$ & & $\begin{array}{l}65.53 \\
(15.3)\end{array}$ & & $\begin{array}{l}61.17 \\
(15.9)\end{array}$ & \\
\hline \multirow[t]{6}{*}{$\begin{array}{l}\text { Alcohol } \\
\text { consumption }\end{array}$} & & & & $<0.001$ & & $<.001$ & & $<0.001$ & & 0.177 \\
\hline & never & 2166 & $\begin{array}{l}68.41 \\
(12.26)\end{array}$ & & $\begin{array}{l}72.24 \\
(13.14)\end{array}$ & & $\begin{array}{l}68.29 \\
(14.81)\end{array}$ & & $\begin{array}{l}62.59 \\
(15.92)\end{array}$ & \\
\hline & occasional & 3107 & $\begin{array}{l}66.86 \\
(11.56)\end{array}$ & & $\begin{array}{l}70.87 \\
(12.02)\end{array}$ & & $\begin{array}{l}66.51 \\
(14.22)\end{array}$ & & $\begin{array}{l}61.09 \\
(15.13)\end{array}$ & \\
\hline & $\begin{array}{l}\text { a little } \\
\text { /day }\end{array}$ & 427 & $\begin{array}{l}65.79 \\
(13.1)\end{array}$ & & $\begin{array}{l}69.01 \\
(13.72)\end{array}$ & & $\begin{array}{l}66.32 \\
(15.8)\end{array}$ & & $\begin{array}{l}60.08 \\
(16.64)\end{array}$ & \\
\hline & some /day & 106 & $\begin{array}{l}65.13 \\
(11.48)\end{array}$ & & $\begin{array}{l}67.94 \\
(13.05)\end{array}$ & & $\begin{array}{l}65.27 \\
(13.62)\end{array}$ & & $\begin{array}{l}60.59 \\
(14.84)\end{array}$ & \\
\hline & much /day & 75 & $\begin{array}{l}59.47 \\
(14.03)\end{array}$ & & $\begin{array}{l}62.57 \\
(15.03)\end{array}$ & & $\begin{array}{l}59.64 \\
(16.3)\end{array}$ & & $\begin{array}{l}54.41 \\
(21.06)\end{array}$ & \\
\hline \multirow[t]{3}{*}{$\begin{array}{l}\text { Bad dietary } \\
\text { habits }\end{array}$} & & & & $<.001$ & & $<.001$ & & $<0.001$ & & $<.001$ \\
\hline & no & 3396 & $\begin{array}{l}69.93 \\
(11.63)\end{array}$ & & $\begin{array}{l}73.33 \\
(12.54)\end{array}$ & & $\begin{array}{l}70.23 \\
(14.21)\end{array}$ & & $\begin{array}{l}64.23 \\
(14.86)\end{array}$ & \\
\hline & yes & 2485 & $\begin{array}{l}63.53 \\
(11.59)\end{array}$ & & $\begin{array}{l}68 \\
(12.27)\end{array}$ & & $\begin{array}{l}62.68 \\
(14.06)\end{array}$ & & $\begin{array}{l}57.72 \\
(15.93)\end{array}$ & \\
\hline
\end{tabular}




\begin{tabular}{|c|c|c|c|c|c|c|c|c|c|c|}
\hline \multirow[t]{2}{*}{ Variables } & & \multirow[t]{2}{*}{$\mathbf{N}$} & \multicolumn{2}{|l|}{ GS } & \multicolumn{2}{|l|}{ PS } & \multicolumn{2}{|l|}{ MS } & \multicolumn{2}{|l|}{ SS } \\
\hline & & & $\begin{array}{l}\text { mean } \\
\text { (sd) }\end{array}$ & $\begin{array}{l}P \\
\text { value }\end{array}$ & $\begin{array}{l}\text { mean } \\
\text { (sd) }\end{array}$ & $\begin{array}{l}P \\
\text { value }\end{array}$ & $\begin{array}{l}\text { mean } \\
\text { (sd) }\end{array}$ & $\begin{array}{l}P \\
\text { value }\end{array}$ & $\begin{array}{l}\text { mean } \\
\text { (sd) }\end{array}$ & $\begin{array}{l}\mathrm{P} \\
\text { value }\end{array}$ \\
\hline \multirow{6}{*}{$\begin{array}{l}\text { Breakfast } \\
\text { consumption } \\
\text { (days/week) }\end{array}$} & & & & $<.001$ & & $<.001$ & & $<0.001$ & & $\begin{array}{l}<.001 \\
0.00\end{array}$ \\
\hline & everyday & 2720 & $\begin{array}{l}69.91 \\
(11.75)\end{array}$ & & $\begin{array}{l}73.06 \\
(12.76)\end{array}$ & & $\begin{array}{l}70.19 \\
(14.53)\end{array}$ & & $\begin{array}{l}64.63 \\
(14.78)\end{array}$ & \\
\hline & $5-6$ & 1562 & $\begin{array}{l}67.08 \\
(11.39)\end{array}$ & & $\begin{array}{l}71.15 \\
(11.94)\end{array}$ & & $\begin{array}{l}66.41 \\
(14.11)\end{array}$ & & $\begin{array}{l}61.66 \\
(14.72)\end{array}$ & \\
\hline & $3-4$ & 848 & $\begin{array}{l}62.97 \\
(11.13)\end{array}$ & & $\begin{array}{l}68.08 \\
(12.05)\end{array}$ & & $\begin{array}{l}61.93 \\
(13.08)\end{array}$ & & $\begin{array}{l}56.43 \\
(15.45)\end{array}$ & \\
\hline & $1-2$ & 609 & $\begin{array}{l}62.69 \\
(12.07)\end{array}$ & & $\begin{array}{l}67.04 \\
(12.62)\end{array}$ & & $\begin{array}{l}62.75 \\
(14.21)\end{array}$ & & $\begin{array}{l}55.87 \\
(16.81)\end{array}$ & \\
\hline & never & 142 & $\begin{array}{l}62.16 \\
(14.29)\end{array}$ & & $\begin{array}{l}67.58 \\
(15.47)\end{array}$ & & $\begin{array}{l}62.54 \\
(17.1)\end{array}$ & & $\begin{array}{l}53.23 \\
(20.14)\end{array}$ & \\
\hline \multirow{6}{*}{$\begin{array}{l}\text { Sunshine } \\
\text { (hours/week) }\end{array}$} & & & & 0.071 & & 0.008 & & 0.170 & & 0.504 \\
\hline & $\geq 14$ & 476 & $\begin{array}{l}68.96 \\
(12.57)\end{array}$ & & $\begin{array}{l}72.22 \\
(13.32)\end{array}$ & & $\begin{array}{l}68.71 \\
(15.1)\end{array}$ & & $\begin{array}{l}64.23 \\
(15.97)\end{array}$ & \\
\hline & $<14$ & 874 & $\begin{array}{l}69.41 \\
(12.12)\end{array}$ & & $\begin{array}{l}73.2 \\
(13.04)\end{array}$ & & $\begin{array}{l}69.58 \\
(14.2)\end{array}$ & & $\begin{array}{l}63.3 \\
(15.74)\end{array}$ & \\
\hline & $<7$ & 1695 & $\begin{array}{l}67.26 \\
(12.14)\end{array}$ & & $\begin{array}{l}71.11 \\
(12.88)\end{array}$ & & $\begin{array}{l}67.18 \\
(14.69)\end{array}$ & & $\begin{array}{l}61.37 \\
(15.31)\end{array}$ & \\
\hline & $<3$ & 1578 & $\begin{array}{l}66.84 \\
(11.84)\end{array}$ & & $\begin{array}{l}70.8 \\
(12.09)\end{array}$ & & $\begin{array}{l}66.64 \\
(14.47)\end{array}$ & & $\begin{array}{l}60.93 \\
(15.96)\end{array}$ & \\
\hline & $<1$ & 1258 & $\begin{array}{l}65.49 \\
(11.54)\end{array}$ & & $\begin{array}{l}69.5 \\
(12.5)\end{array}$ & & $\begin{array}{l}64.96 \\
(14.53)\end{array}$ & & $\begin{array}{l}59.98 \\
(15.32)\end{array}$ & \\
\hline \multirow{6}{*}{$\begin{array}{l}\text { Physical } \\
\text { exercise } \\
\text { (days/week) }\end{array}$} & & & & $<0.001$ & & $<0.001$ & & $<0.001$ & & $\begin{array}{l}<.001 \\
0.01\end{array}$ \\
\hline & everyday & 630 & $\begin{array}{l}72.14 \\
(11.89)\end{array}$ & & $\begin{array}{l}74.46 \\
(12.84)\end{array}$ & & $\begin{array}{l}73.24 \\
(14.82)\end{array}$ & & $\begin{array}{l}67.07 \\
(15.12)\end{array}$ & \\
\hline & $5-6$ & 613 & $\begin{array}{l}68.96 \\
(12.27)\end{array}$ & & $\begin{array}{l}71.93 \\
(13.02)\end{array}$ & & $\begin{array}{l}68.74 \\
(14.89)\end{array}$ & & $\begin{array}{l}64.63 \\
(15.28)\end{array}$ & \\
\hline & $3-4$ & 1412 & $\begin{array}{l}67.67 \\
(12.71)\end{array}$ & & $\begin{array}{l}71.57 \\
(13.24)\end{array}$ & & $\begin{array}{l}67.64 \\
(14.63)\end{array}$ & & $\begin{array}{l}61.62 \\
(16.82)\end{array}$ & \\
\hline & $1-2$ & 2375 & $\begin{array}{l}66.24 \\
(11.17)\end{array}$ & & $\begin{array}{l}70.57 \\
(11.82)\end{array}$ & & $\begin{array}{l}65.6 \\
(14.03)\end{array}$ & & $\begin{array}{l}60.36 \\
(14.57)\end{array}$ & \\
\hline & never & 851 & $\begin{array}{l}64.36 \\
(11.82)\end{array}$ & & $\begin{array}{l}68.58 \\
(13.21)\end{array}$ & & $\begin{array}{l}64.25 \\
(14.43)\end{array}$ & & $\begin{array}{l}57.92 \\
(15.78)\end{array}$ & \\
\hline \multirow{2}{*}{$\begin{array}{l}\text { Bedtime } \\
\text { before } 11 \mathrm{pm} \\
\text { (days/week) }\end{array}$} & & & & 0.019 & & 0.003 & & 0.146 & & 0.388 \\
\hline & everyday & 1119 & $\begin{array}{l}70.05 \\
(12.09)\end{array}$ & & $\begin{array}{l}73 \\
(13.41)\end{array}$ & & $\begin{array}{l}70.84 \\
(14.86)\end{array}$ & & $\begin{array}{l}64.43 \\
(15.44)\end{array}$ & \\
\hline$\star * P<0.01$ & & & & & & & & & & \\
\hline
\end{tabular}




\begin{tabular}{|c|c|c|c|c|c|c|c|c|c|c|}
\hline \multirow[t]{2}{*}{ Variables } & & \multirow[t]{2}{*}{$\mathbf{N}$} & \multicolumn{2}{|l|}{ GS } & \multicolumn{2}{|l|}{ PS } & \multicolumn{2}{|l|}{ MS } & \multicolumn{2}{|l|}{ SS } \\
\hline & & & $\begin{array}{l}\text { mean } \\
\text { (sd) }\end{array}$ & $\begin{array}{l}P \\
\text { value }\end{array}$ & $\begin{array}{l}\text { mean } \\
\text { (sd) }\end{array}$ & $\begin{array}{l}\mathrm{P} \\
\text { value }\end{array}$ & $\begin{array}{l}\text { mean } \\
\text { (sd) }\end{array}$ & $\begin{array}{l}\mathrm{P} \\
\text { value }\end{array}$ & $\begin{array}{l}\text { mean } \\
\text { (sd) }\end{array}$ & $\begin{array}{l}\mathrm{P} \\
\text { value }\end{array}$ \\
\hline & $5-6$ & 1007 & $\begin{array}{l}68.35 \\
(12.1)\end{array}$ & & $\begin{array}{l}71.61 \\
(12.73)\end{array}$ & & $\begin{array}{l}68.44 \\
(14.51)\end{array}$ & & $\begin{array}{l}63.17 \\
(14.79)\end{array}$ & \\
\hline & $3-4$ & 1236 & $\begin{array}{l}66.23 \\
(12.38)\end{array}$ & & $\begin{array}{l}70.11 \\
(12.87)\end{array}$ & & $\begin{array}{l}65.98 \\
(14.54)\end{array}$ & & $\begin{array}{l}60.52 \\
(16.01)\end{array}$ & \\
\hline & $1-2$ & 1549 & $\begin{array}{l}66.1 \\
(11.3)\end{array}$ & & $\begin{array}{l}70.48 \\
(11.97)\end{array}$ & & $\begin{array}{l}65.56 \\
(13.79)\end{array}$ & & $\begin{array}{l}59.98 \\
(15.51)\end{array}$ & \\
\hline & never & 970 & $\begin{array}{l}65.87 \\
(11.96)\end{array}$ & & $\begin{array}{l}70.52 \\
(12.49)\end{array}$ & & $\begin{array}{l}64.92 \\
(14.95)\end{array}$ & & $\begin{array}{l}59.9 \\
(15.92)\end{array}$ & \\
\hline \multirow{6}{*}{$\begin{array}{l}\text { Sleep } \\
\text { duration } \\
\text { (hours) }\end{array}$} & & & & $<001$ & & $<0.001$ & & $<0.001$ & & $\begin{array}{l}<.001 \\
0.01\end{array}$ \\
\hline & $\geq 9$ & 503 & $\begin{array}{l}67.91 \\
(12.95)\end{array}$ & & $\begin{array}{l}71.48 \\
(13.65)\end{array}$ & & $\begin{array}{l}68.26 \\
(15.34)\end{array}$ & & $\begin{array}{l}61.88 \\
(16.59)\end{array}$ & \\
\hline & $<9$ & 3792 & $\begin{array}{l}68.51 \\
(11.63)\end{array}$ & & $\begin{array}{l}72.57 \\
(12.3)\end{array}$ & & $\begin{array}{l}68.18 \\
(14.41)\end{array}$ & & $\begin{array}{l}62.64 \\
(14.86)\end{array}$ & \\
\hline & $<7$ & 1402 & $\begin{array}{l}64.85 \\
(11.67)\end{array}$ & & $\begin{array}{l}68.1 \\
(12.4)\end{array}$ & & $\begin{array}{l}64.82 \\
(14.23)\end{array}$ & & $\begin{array}{l}59.85 \\
(15.96)\end{array}$ & \\
\hline & $<5$ & 145 & $\begin{array}{l}56.75 \\
(13.13)\end{array}$ & & $\begin{array}{l}62.18 \\
(12.6)\end{array}$ & & $\begin{array}{l}56.71 \\
(14.61)\end{array}$ & & $\begin{array}{l}48.37 \\
(18.9)\end{array}$ & \\
\hline & $<3$ & 39 & $\begin{array}{l}57.77 \\
(11.65)\end{array}$ & & $\begin{array}{l}61.77 \\
(13.69)\end{array}$ & & $\begin{array}{l}59.19 \\
(14.4)\end{array}$ & & $\begin{array}{l}49.64 \\
(21.62)\end{array}$ & \\
\hline \multirow{5}{*}{$\begin{array}{l}\text { Surfing the } \\
\text { internet } \\
\text { (hours) }\end{array}$} & & & & 0.062 & & 0.154 & & $<0.001$ & & 0.983 \\
\hline & $<3$ & 3019 & $\begin{array}{l}67.78 \\
(12.6)\end{array}$ & & $\begin{array}{l}71.09 \\
(13.24)\end{array}$ & & $\begin{array}{l}68.39 \\
(15)\end{array}$ & & $\begin{array}{l}61.83 \\
(16.37)\end{array}$ & \\
\hline & $<5$ & 1739 & $\begin{array}{l}67.06 \\
(11.4)\end{array}$ & & $\begin{array}{l}71.17 \\
(12.07)\end{array}$ & & $\begin{array}{l}66.51 \\
(14)\end{array}$ & & $\begin{array}{l}61.42 \\
(14.75)\end{array}$ & \\
\hline & $<7$ & 720 & $\begin{array}{l}66.49 \\
(10.86)\end{array}$ & & $\begin{array}{l}71.46 \\
(11.59)\end{array}$ & & $\begin{array}{l}64.66 \\
(13.94)\end{array}$ & & $\begin{array}{l}61.18 \\
(14.46)\end{array}$ & \\
\hline & $\geq 7$ & 403 & $\begin{array}{l}65.07 \\
(12.05)\end{array}$ & & $\begin{array}{l}69.91 \\
(13.1)\end{array}$ & & $\begin{array}{l}63.53 \\
(14.39)\end{array}$ & & $\begin{array}{l}59.59 \\
(15.91)\end{array}$ & \\
\hline
\end{tabular}


Table 3

Comparison of SHS with different living environmental factors (mean (sd))

\begin{tabular}{|c|c|c|c|c|c|c|c|c|c|c|}
\hline \multirow[t]{2}{*}{ Variables } & & \multirow{2}{*}{$\begin{array}{l}\mathrm{N} \\
(\%)\end{array}$} & \multicolumn{2}{|l|}{ GS } & \multicolumn{2}{|l|}{ PS } & \multicolumn{2}{|l|}{ MS } & \multicolumn{2}{|l|}{ SS } \\
\hline & & & $\begin{array}{l}\text { mean } \\
\text { (sd) }\end{array}$ & $\begin{array}{l}P \\
\text { value }\end{array}$ & $\begin{array}{l}\text { mean } \\
\text { (sd) }\end{array}$ & $\begin{array}{l}P \\
\text { value }\end{array}$ & $\begin{array}{l}\text { mean } \\
\text { (sd) }\end{array}$ & $\begin{array}{l}P \\
\text { value }\end{array}$ & $\begin{array}{l}\text { mean } \\
\text { (sd) }\end{array}$ & $\begin{array}{l}\mathrm{P} \\
\text { value }\end{array}$ \\
\hline \multirow[t]{4}{*}{ Greenery } & & & & 0.002 & & 0.358 & & 0.011 & & $\begin{array}{l}<.001 \\
0.001\end{array}$ \\
\hline & bad & 3105 & & & & & & & & \\
\hline & & & $\begin{array}{l}65.65 \\
(11.58)\end{array}$ & & $\begin{array}{l}69.99 \\
(12.44)\end{array}$ & & $\begin{array}{l}65.25 \\
(14.17)\end{array}$ & & $\begin{array}{l}59.42 \\
(15.1)\end{array}$ & \\
\hline & good & 2776 & $\begin{array}{l}68.99 \\
(12.28)\end{array}$ & & $\begin{array}{l}72.3 \\
(12.88)\end{array}$ & & $\begin{array}{l}69.04 \\
(14.87)\end{array}$ & & $\begin{array}{l}63.77 \\
(15.94)\end{array}$ & \\
\hline \multirow[t]{3}{*}{ Air } & & & & 0.002 & & 0.005 & & 0.001 & & 0.274 \\
\hline & bad & 2977 & $\begin{array}{l}65.72 \\
(11.47)\end{array}$ & & $\begin{array}{l}69.86 \\
(12.24)\end{array}$ & & $\begin{array}{l}65.21 \\
(14.35)\end{array}$ & & $\begin{array}{l}59.99 \\
(15.32)\end{array}$ & \\
\hline & fresh & 2904 & $\begin{array}{l}68.76 \\
(12.39)\end{array}$ & & $\begin{array}{l}72.34 \\
(13.04)\end{array}$ & & $\begin{array}{l}68.92 \\
(14.67)\end{array}$ & & $\begin{array}{l}63 \\
(15.85)\end{array}$ & \\
\hline \multirow[t]{3}{*}{ Noiseless } & & & & 0.788 & & 0.159 & & 0.477 & & 0.905 \\
\hline & no & 4019 & $\begin{array}{l}66.53 \\
(12.08)\end{array}$ & & $\begin{array}{l}70.4 \\
(12.69)\end{array}$ & & $\begin{array}{l}66.35 \\
(14.83)\end{array}$ & & $\begin{array}{l}60.75 \\
(15.82)\end{array}$ & \\
\hline & yes & 1862 & $\begin{array}{l}68.72 \\
(11.79)\end{array}$ & & $\begin{array}{l}72.54 \\
(12.61)\end{array}$ & & $\begin{array}{l}68.53 \\
(14.07)\end{array}$ & & $\begin{array}{l}63.03 \\
(15.19)\end{array}$ & \\
\hline \multirow[t]{3}{*}{$\begin{array}{l}\text { Pleasant } \\
\text { housing }\end{array}$} & & & & $<.001$ & & 0.036 & & $\begin{array}{l}<.001 \\
0.00\end{array}$ & & 0.003 \\
\hline & no & 824 & $\begin{array}{l}63.54 \\
(11.55)\end{array}$ & & $\begin{array}{l}68.55 \\
(12.47)\end{array}$ & & $\begin{array}{l}62.34 \\
(14.12)\end{array}$ & & $\begin{array}{l}57.36 \\
(15.46)\end{array}$ & \\
\hline & yes & 5057 & $\begin{array}{l}67.83 \\
(12)\end{array}$ & & $\begin{array}{l}71.49 \\
(12.69)\end{array}$ & & $\begin{array}{l}67.81 \\
(14.57)\end{array}$ & & $\begin{array}{l}62.15 \\
(15.58)\end{array}$ & \\
\hline \multirow[t]{3}{*}{$\begin{array}{l}\text { Spacious } \\
\text { rooms }\end{array}$} & & & & 0.003 & & 0.434 & & $\begin{array}{l}<.001 \\
0.00\end{array}$ & & 0.186 \\
\hline & yes & 663 & $\begin{array}{l}63.6 \\
(10.82)\end{array}$ & & $\begin{array}{l}68.83 \\
(11.92)\end{array}$ & & $\begin{array}{l}61.61 \\
(13.48)\end{array}$ & & $\begin{array}{l}58.13 \\
(15.11)\end{array}$ & \\
\hline & no & 5218 & $\begin{array}{l}67.69 \\
(12.1)\end{array}$ & & $\begin{array}{l}71.37 \\
(12.77)\end{array}$ & & $\begin{array}{l}67.73 \\
(14.62)\end{array}$ & & $\begin{array}{l}61.9 \\
(15.67)\end{array}$ & \\
\hline \multirow[t]{3}{*}{$\begin{array}{l}\text { Neighbor } \\
\text { harmony }\end{array}$} & & & & $\begin{array}{l}< \\
0.001\end{array}$ & & $\begin{array}{l}< \\
0.001\end{array}$ & & $\begin{array}{l}<.001 \\
0.001\end{array}$ & & $\begin{array}{l}< \\
0.001\end{array}$ \\
\hline & no & 3351 & $\begin{array}{l}65.47 \\
(11.67)\end{array}$ & & $\begin{array}{l}69.76 \\
(12.57)\end{array}$ & & $\begin{array}{l}65.02 \\
(14.19)\end{array}$ & & $\begin{array}{l}59.4 \\
(15.5)\end{array}$ & \\
\hline & yes & 2530 & $\begin{array}{l}69.55 \\
(12.11)\end{array}$ & & $\begin{array}{l}72.84 \\
(12.67)\end{array}$ & & $\begin{array}{l}69.72 \\
(14.77)\end{array}$ & & $\begin{array}{l}64.22 \\
(15.44)\end{array}$ & \\
\hline
\end{tabular}




\begin{tabular}{|c|c|c|c|c|c|c|c|c|c|c|}
\hline \multirow[t]{2}{*}{ Variables } & & \multirow{2}{*}{$\begin{array}{l}\mathrm{N} \\
(\%)\end{array}$} & \multicolumn{2}{|l|}{ GS } & \multicolumn{2}{|l|}{ PS } & \multicolumn{2}{|l|}{ MS } & \multicolumn{2}{|l|}{ SS } \\
\hline & & & $\begin{array}{l}\text { mean } \\
\text { (sd) }\end{array}$ & $\begin{array}{l}P \\
\text { value }\end{array}$ & $\begin{array}{l}\text { mean } \\
\text { (sd) }\end{array}$ & $\begin{array}{l}P \\
\text { value }\end{array}$ & $\begin{array}{l}\text { mean } \\
\text { (sd) }\end{array}$ & $\begin{array}{l}P \\
\text { value }\end{array}$ & $\begin{array}{l}\text { mean } \\
\text { (sd) }\end{array}$ & $\begin{array}{l}\mathrm{P} \\
\text { value }\end{array}$ \\
\hline \multirow{3}{*}{$\begin{array}{l}\text { Fitness } \\
\text { facility }\end{array}$} & & & & 0.001 & & 0.058 & & 0.001 & & 0.001 \\
\hline & few & 4766 & $\begin{array}{l}66.4 \\
(11.66)\end{array}$ & & $\begin{array}{l}70.44 \\
(12.41)\end{array}$ & & $\begin{array}{l}66.15 \\
(14.31)\end{array}$ & & $\begin{array}{l}60.46 \\
(15.42)\end{array}$ & \\
\hline & many & 1115 & $\begin{array}{l}70.74 \\
(12.92)\end{array}$ & & $\begin{array}{l}73.81 \\
(13.53)\end{array}$ & & $\begin{array}{l}70.86 \\
(15.34)\end{array}$ & & $\begin{array}{l}65.8 \\
(15.9)\end{array}$ & \\
\hline \multirow[t]{3}{*}{$\begin{array}{l}\text { Living } \\
\text { convenience }\end{array}$} & & & & $<.001$ & & $<.001$ & & $<.001$ & & $<.001$ \\
\hline & no & 3832 & $\begin{array}{l}65.59 \\
(11.91)\end{array}$ & & $\begin{array}{l}69.68 \\
(12.62)\end{array}$ & & $\begin{array}{l}65.41 \\
(14.53)\end{array}$ & & $\begin{array}{l}59.45 \\
(15.68)\end{array}$ & \\
\hline & yes & 2049 & $\begin{array}{l}70.29 \\
(11.66)\end{array}$ & & $\begin{array}{l}73.7 \\
(12.44)\end{array}$ & & $\begin{array}{l}70.09 \\
(14.32)\end{array}$ & & $\begin{array}{l}65.25 \\
(14.9)\end{array}$ & \\
\hline
\end{tabular}

Table 4

Fitting effect of the structural equation models

\begin{tabular}{|llcccc|}
\hline Models & CMIN/DF & CFI & GFI & AGFI & RMSEA \\
\hline Criterion for good fit ${ }^{\text {[13] }}$ & $<5$ & $>0.95$ & $>0.95$ & $>0.95$ & $<0.05$ \\
\hline Model 1 & 5.697 & 0.947 & 0.957 & 0.946 & 0.028 \\
\hline Model 2 & 5.297 & 0.956 & 0.979 & 0.970 & 0.027 \\
\hline Model 3 & 4.507 & 0.972 & 0.983 & 0.976 & 0.024 \\
\hline Model 4 & 4.269 & 0.974 & 0.986 & 0.980 & 0.024 \\
\hline $\begin{array}{l}\text { Model 1: Structural model for lifestyle, environment, and general sub-health status, } \\
\text { Model 2: Structural model for lifestyle, environment, and physical sub-health status, } \\
\text { Model 3: Structural model for lifestyle, environment, and mental sub-health status, } \\
\text { Model 4: Structural model for lifestyle, environment, and social sub-health status }\end{array}$ \\
\hline
\end{tabular}


Table 5

The associations between lifestyle, environment, and SHS as analyzed through structural equation modeling

\begin{tabular}{|clllll|}
\hline SHS & Factors & Standardized effect & 95\% Cl lower limit & $95 \%$ Cl upper limit & P \\
\hline GS & Lifestyle & -0.371 & -0.406 & -0.335 & $<0.001$ \\
& Environment & 0.282 & 0.246 & 0.317 & $<0.001$ \\
\hline PS & Lifestyle & -0.418 & -0.456 & -0.377 & $<0.001$ \\
\hline & Environment & 0.225 & 0.182 & 0.265 & $<0.001$ \\
\hline MS & Lifestyle & -0.306 & -0.338 & -0.273 & $<0.001$ \\
\hline & Environment & 0.286 & 0.252 & 0.321 & $<0.001$ \\
\hline SS & Lifestyle & -0.274 & -0.309 & -0.242 & $<0.001$ \\
\hline & Environment & 0.263 & 0.227 & 0.299 & $<0.001$ \\
\hline
\end{tabular}

\section{Figures}

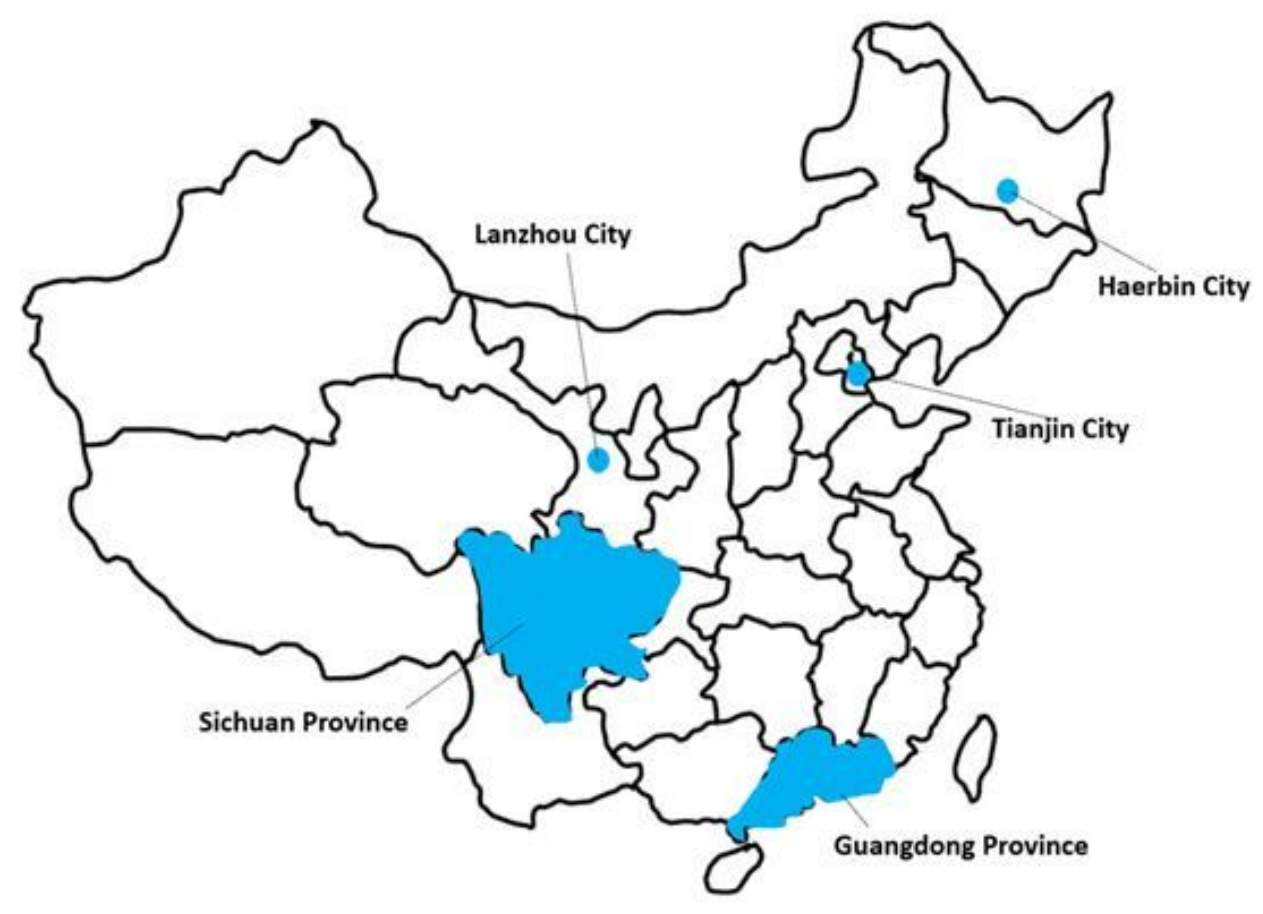

Figure 1

Sampling points in the survey on the map of China. Note: The designations employed and the presentation of the material on this map do not imply the expression of any opinion whatsoever on the part of Research Square concerning 
the legal status of any country, territory, city or area or of its authorities, or concerning the delimitation of its frontiers or boundaries. This map has been provided by the authors.
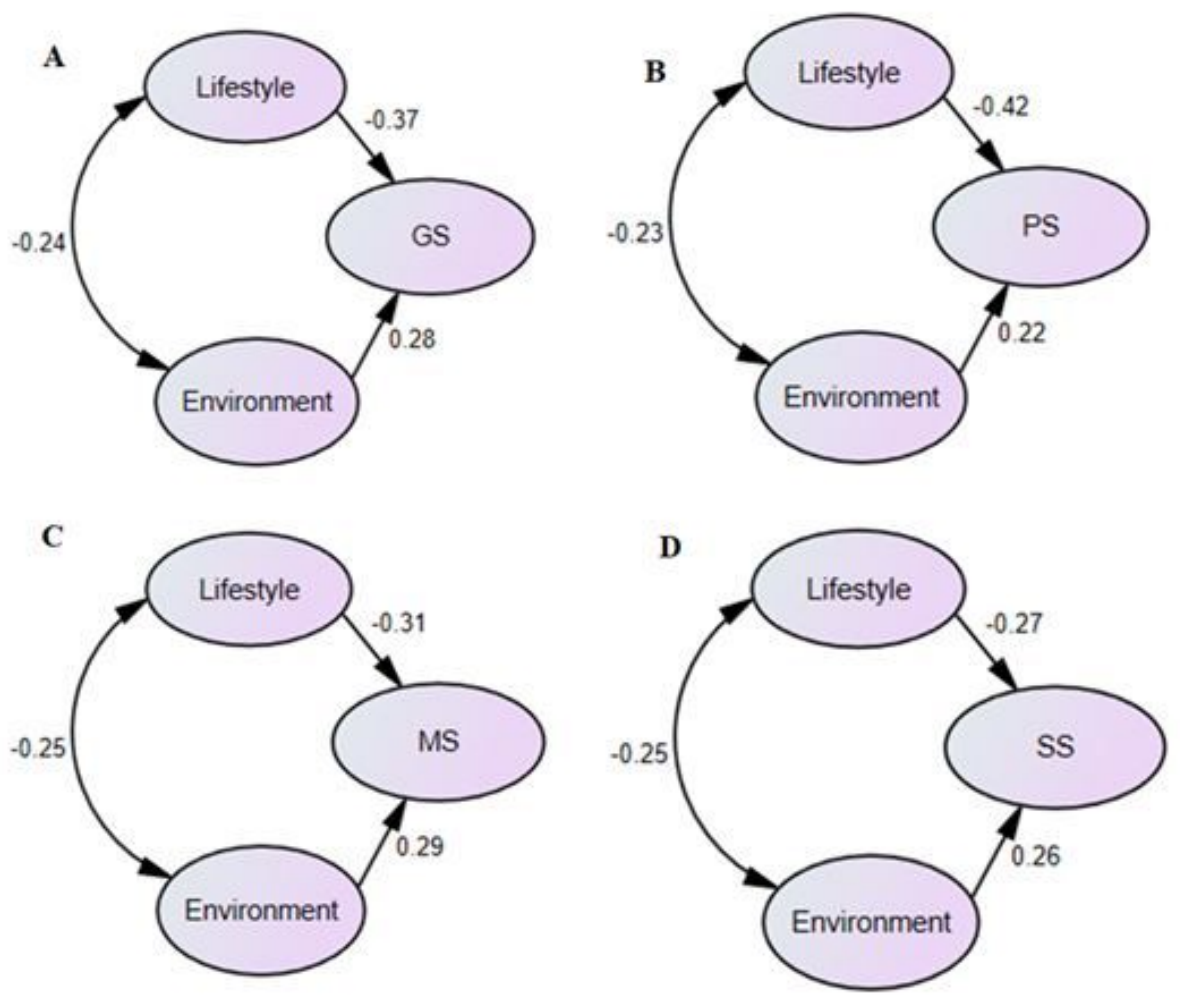

\section{Figure 2}

Structural equation model involving lifestyle, environment, and $S H S(A=G S, B=P S, C=M S$, and $D=S S)$ 